\title{
Molecular Genetic Characteristics of Methicillin-Resistant Staphylococcus aureus Isolated from Patients and Environment of General Hospital Intensive Care Unit in a Chungnam Province, Korea
}

\author{
Hye-Suk Kim ${ }^{1, \dagger}$, Sung-Bae Park ${ }^{2, \dagger}$, Sang-Ha Kim³ ${ }^{3}$ Sunghyun $\mathrm{Kim}^{2}$, Sung-Hee Hyun ${ }^{4}$, \\ Young-Kwon Kim ${ }^{5}$ \\ Department of Laboratory Medicine, Hongsung Medical Center, Hongseong, Korea \\ ${ }^{2}$ Department of Clinical Laboratory Science, College of Health Sciences, Catholic University of Pusan, Busan, Korea \\ ${ }^{3}$ Department of Laboratory Medicine, Konyang University Hospital, Daejeon, Korea \\ ${ }^{4}$ Department of Biomedical Laboratory Science, School of Medicine, Eulji University, Daejeon, Korea \\ ${ }^{5}$ Department of Biomedical Laboratory Science, College of Medical Sciences, Konyang University, Daejeon, Korea
}

\section{충남지역 종합병원 중환자실 환경과 환자로부터 분리한 메티실린 내성 황색포도알균(MRSA)의 분자유전학적 특성}

김혜숙 ${ }^{1 \dagger}$, 박성배 $^{2, \dagger}$, 김상하 ${ }^{3}$, 김성현 $^{2}$, 현성희 $^{4}$, 김영권 ${ }^{5}$

${ }^{1}$ 홍성의료원 진단검사의학과, ${ }^{2}$ 부산가톨릭대학교 보건과학대학 임상병리학과, ${ }^{3}$ 건양대학교병원 진단검사의학과, ${ }^{4}$ 을지대학교 의과대학 임상병리학과, ${ }^{5}$ 건양대학교 의과학대학 임상병리학과

In the present study, mec complex typing and SCCmec typing were performed to analyze the molecular genetic characteristics of 20 methicillin-resistant Staphylococcus aureus (MRSA) strains isolated from clinical specimens and 4 strains isolated from the ICU environments of secondary medical institutions in a Chungnam province, Korea, from June to July of 2017. Among a total of 20 MRSA strains isolated from clinical specimens, 8 cases (40\%) were SCC mectype II, one case (5\%) was SCCmec type IVa, and 11 cases (55\%) were not-typeable in SCCmectype analysis. Among 4 MRSA isolates from the ICU environment, one strain did not have the mecA gene and 3 strains were typed as SCC mec types II, III, and IVa, respectively. Data from the present study showed that the origin of MRSA isolated from the clinical specimens was different from those from the ICU environment in most cases but the origin was concordant in one case. In this case, MRSA might be transmitted by healthcare workers to the ICU environment. Further study with a large number of cases and other hospital infection-related microorganisms will be needed. This continuous follow-up study might provide useful information on infection control in medical institutions.

Key words: ICU, mec complex type, Molecular genetic characteristics, MRSA, SCCmec type

This is an Open Access article distributed under the terms of the Creative Commons Attribution Non-Commercial License (http://creativecommons.org/licenses/by-nc/4.0) which permits unrestricted non-commercial use, distribution, and reproduction in any medium, provided the original work is properly cited.

Copyright @ 2018 The Korean Society for Clinical Laboratory Science. All rights reserved.
${ }^{\dagger}$ The first two authors contribute the same to this paper.

Corresponding author: Young-Kwon Kim Department of Biomedical Laboratory Science, College of Medical Sciences, Konyang

University, 158 Gwanjeodong-ro, Seo-gu,

Daejeon 35365, Korea

Tel: 82-42-660-6371

Fax: 82-42-543-6370

E-mail:ykkim3245@konyang.ac.kr

Co-Corresponding author: Sung-Hee Hyun Department of Biomedical Laboratory Science, School of Medicine, Eulji University, 77 Gyeryong-ro, 771 beon-gil, Jung-gu, Daejeon 34824, Korea

Tel: 82-42-259-1751

Fax: 82-42-259-1759

E-mail: hyunsh@eulji.ac.kr

Received: February 20, 2018

Revised $1^{\text {st. }}$ April 18, 2018

Revised $2^{\text {nd. }}:$ May 10, 2018

Revised 3 $3^{\text {rd. }}$ : May 17, 2018

Accepted: May 22, 2018 


\section{서 론}

의료관련감염(Healthcare-associated infection, HAI)은 입원 당시 감염이 존재하지 않을 뿐만 아니라 잠복감염 또한 없 는 상태에서 입원 3 일 후에 발생한 감염으로 입원, 외래 진료 및 의료와 관련된 모든 감염을 의미한다[1, 2]. 2011년 대한의료관 련감염관리학회의 보고에 따르면 입원 환자의 HAI 발생률이 약 5 10\% 정도로 추정되고 있으며, 이에 질병관리본부에서는 2011년부터 HAI에서 가장 문제가 되는 메티실린 내성 황색포 도알균(Methicillin-resistant Staphylococcus aureus, MRSA), 반코마이신 내성 장알균(Vancomycin-resistant Enterococcus, $\mathrm{VRE}$ ), 반코마이신 내성 황색포도알균(Vancomycin-resistant Staphylococcus aureus, VRSA), 다제 내성 녹농균(Multidrugresistant Psedomonas aerusinosa, MRPA), 다제 내성 아시네 토박터 바우마니균(Multidrug-resistant Acinetobacter baumannii, MRAB), 카바페넴 내성 장내세균 속(Carbapenemresistant Enterobacteriaceae, $\mathrm{CRE}$ )등 6종의 의료관련 감염 체를 지정하여 관리하고 있으며, 2017년에 의료관련감염병 관 리지침에는 반코마이신내성황색포도알균(VRSA) 감염증과 카 바페넴내성장내세균속균종 $(\mathrm{CRE})$ 감염증이 감염병의 예방 및 관리에 관한 법률 제 2 조 1 항 및 2항에 제 2 급 감염병에 삽입되어 전파가능성을 고려하여 발생 또는 유행 시 24시간 이내에 신고 하여야 하고, 격리가 필요한 감염병으로 개정되어 있는 상황이 다[1, 3].

병원감염을 감소시키기 위한 선행 전략으로는 손 위생, 격리, 의료관련 감염감시, 요로감염 및 폐렴, 수술부위 감염 및 혈관 카테터 관련 균혈증, 직원 감염관리, 소독과 멸균의 지침 등이 주요활동 내용이었다[4]. 하지만, 병원 내 환경에는 수 많은 종 류의 미생물이 존재하고 있고, 기회감염균에 노출될 가능성이 높으며, 감염 시 심각한 문제가 발생할 가능성이 있다[5, 6]. 또 한 의료 종사자의 손, 인공호흡기, 서킷, 산소 측정기, 마스크, 침 대 난간, 약물 자동 주입기 등에서도 다제 내성균이 발생하고 있 는 것으로 보고 되고 있으며[7], 환자 침대, 사물함뿐만 아니라 의료종사자의 출입 카드, 청진기, 전화기 등이 병원소가 되기도 한다[3, 4]. 또한 일반 병실보다 중환자실의 환자에서 분리되는 병원감염 관련 균주의 내성률이 높은 것으로 보고되었으며 $[8$, 9], 일반적으로 $S$. aureus는 지역사회에서의 보균율이 낮은 것 으로 알려져 있다. 1961년 영국에서 처음 보고된 MRSA는 병원 감염의 가장 중요한 원인균으로 인식되고 있다[10]. 노령인구 의 증가, 면역저하자의 증가, 항생제 내성균의 증가와 의료기술 의 발전으로 인한 침습적 시술의 증가 등 주요 원인으로 인해 항
생제 내성균의 발생과 전파가 용이해져 병원감염에 이환 될 가 능성이 높고, 입원환자의 경우 재원일 수 증가로 인한 의료비 상 승과 사망률 증가가 동반될 수 있다[11]. MRSA는 주로 의료관 련 MRSA (Healthcare-associated MRSA, HA-MRSA)로 사람 의 피부감염, 균혈증, 폐렴 등 다양한 감염증의 원인이 되는 주 요 세균으로 원내감염의 가장 대표적인 원인균이다[12]. 지역 사회관련 MRSA (Community-associated MRSA, CA-MRSA) 와는 유전형의 차이가 있는 것으로 보고되었다[13, 14]. 미국 $\mathrm{CDC}$ 의 정의에 따르면, 외래환자 또는 입원 48시간 이내 환자의 검체에서 MRSA가 분리되는 경우와 MRSA 분리에 대한 과거력 이 없는 경우, 그리고 과거 1 년 동안 입원이나 장기 요양시설에 입원, 투석, 수술을 하지 않은 환자에서 MRSA가 분리된 경우 CA-MRSA라고 정의하고 있다[15]. 국내 의료기관에서의 MRSA 분리율은 60 70\%로, 중소 병원에서 MRSA 감염률이 약 $40 \%$ 이상을 차지하고 있고, 3 차 병원에서는 약 60 70\%가 항생제 에 대한 내성을 지니고 있음이 보고된 바 있다[16].

따라서, 본 연구에서는 중환자실 환경 중 노출이 빈번한 출입 문 번호 키, 세면대, 수액 조절 펌프, 업무용 컴퓨터 키보드, 유선 전화기 버튼을 대상으로 세균 배양을 실시하여 분리된 세균의 분리 빈도 및 항생제 감수성 시험 결과를 분석하고, 중환자실 환 경과 환자의 임상검체로부터 분리된 MRSA 균주 간의 분자유전 학적 특성을 비교 분석하기 위해 Staphylococcal cassette chromosome (SCC) mec typing과 mec complex typing을 시행하였고, 본 연구 결과를 MRSA에 의한 의료기관 내 HAI에 관한 감염관리를 위한 기초자료로 활용하고자 하였다.

\section{재료 및 방법}

\section{1. 재료}

2017년 6월부터 7월까지 국내의 충남지역 소재 2차 의료기

Table 1. Number of collected specimens from the ICU environments in a general hospital

\begin{tabular}{llc}
\hline \multicolumn{2}{c}{ Sample collection sites } & $\begin{array}{c}\text { No. of specimens } \\
(\%)\end{array}$ \\
\hline Health care zone & Door Number Keypad & $4(8)$ \\
& Hand washing sink & $6(12)$ \\
& Keyboard & $6(12)$ \\
& Telephone & $6(12)$ \\
Patient zone & HCWs hand (ICU)* & $8(16)$ \\
Control & Infusion pump & $12(24)$ \\
Total & Non-HCWs hand & $8(16)$ \\
\hline
\end{tabular}

*HCW, healthcare worker. 
관 내 중환자실 근무자 8명과 대조군으로 환자 비접점 부서 근 무자 8 명의 손과, 중환자실 내 의료 영역과 환자 영역의 환경(출 입문 번호 키, 세면대, 수액조절 펌프, 업무용 컴퓨터 키보드, 유 선 전화기 버튼)으로부터 분리된 MRSA 4주와 임상검체로부터 분리된 MRSA 20주, 총 24주의 MRSA를 대상으로 분자유전학 적 특성을 분석 하였다(Table 1).

\section{2. 분리된 세균의 동정}

환경검체에서 분리된 세균 중 Gram 염색을 시행하여 Gram 양성세균 및 Gram음성세균을 분리하였고, VITEK II compact (bioMérieux, Inc., NC, USA) 자동화 동정 시스템으로 동정하 였다.

\section{3. 항균제 감수성 시험}

혈액우무배지(blood agar plate, BAP)에서 유의한 집락을 $0.45 \%$ 식염수에 부유시켜 McFarland No 0.6 0.9 되게 탁도 를 맞춘 후 VITEK II 장비를 이용하여 항균제 감수성 시험을 시 행하였다. 항균제 감수성 시험 시행 후 감수성 판정은 Clinical and Laboratory Standards Institute (CLSI) 표준값을 적용하 였다. 결과의 정확도를 위해 S. aureus 표준균주(ATCC 29213) 를 사용하여 주 1 회 임상검체와 동일한 방법으로 감수성검사를 실시하여 CLSI 기준 허용범위에 적절한지 확인하였다.

항균제 감수성 시험에 사용된 항균제는 enzylpenicillin, erythromycin, fusidic acid, linezolid, oxacillin, ciprofloxacin, clindamycin, mupirocin, nitrofurantoin, rifampicin, gentamicin, habekacin, quinupristin/dalfopristin, teicoplanin, telithromycin, tetracycline, tigecycline, trimethoprim-sulfamethoxazole, vancomycin을 포함해 총 19 종이다.

\section{MRSA 균주로부터 genomic DNA의 분리}

$\mathrm{BAP}$ 에서 배양된 세균 1 2 집락을 백금이로 취한 후 5\% Chelex ${ }^{\circledR} 100$ Resin (Bio-Rad, Hercules, CA, USA)/TBE solution $500 \mu \mathrm{L}$ 에 혼탁 시킨 후 $100^{\circ} \mathrm{C}$ 에서 10 분간 끓인 후 $6,032 \times \mathrm{g}$ 로 2 분간 원심분리한 상층액을 새 tube에 옮겨 분석 시 까지 보관하였고, 추출한 genomic DNA (gDNA)는 Nanodrop 2,000 (Thermo Fisher Scientific, MC, USA)을 이 용해 그 농도와 순도를 측정하였다.

\section{5. mecA 유전자 검출 및 multiplex $\mathrm{PCR}$ 을 이용한 $\mathrm{SCCmec}$ 과 mec complex typing}

mecA 유전자 검출 및 SCCmec, mec complex typing을 수 행하기 위해 Prime Taq PCR Premix (GeNet Bio, Daejon, Korea) $10 \mu \mathrm{L}$, Forward 와 Reverse primer의 농도를 각각 $10 \mathrm{pmole} / \mu \mathrm{L}$, 추출한 gDNA를 주형 DNA로 $1 \mu \mathrm{L}$, 멸균 증류수 $7 \mu \mathrm{L}$ 를 첨가하여 총 $20 \mu \mathrm{L}$ 의 혼합액을 만들어 multiplex PCR

Table 2. Specific oligonucleotide primer sets used for subtyping of SCCmec types in methicillin-resistant Staphylococcus aureus isolates

\begin{tabular}{|c|c|c|c|c|}
\hline Target region & & Nucleotide sequences $\left(5^{\prime}-3^{\prime}\right)$ & Amplicon size (bp) & Reference \\
\hline \multirow[t]{2}{*}{ ScCmec type I } & $\mathrm{F}$ & GCT TTA AAG AGT GTC GTT ACA GG & 613 & Zhang et al, 2005 [17] \\
\hline & $\mathrm{R}$ & GTT CTC TCA TAG TAT GAC GTC C & & \\
\hline \multirow[t]{2}{*}{ SCCmec type II } & $\mathrm{F}$ & CGT TGA AGA TGA TGA AGC G & 398 & \\
\hline & $\mathrm{R}$ & CGA AAT CAA TGG TTA ATG GAC C & & \\
\hline \multirow[t]{2}{*}{ SCCmec type III } & $\mathrm{F}$ & CCA TAT TGT GTA CGA TGC G & 280 & \\
\hline & $R$ & CCT TAG TTG TCG TAA CAG ATC G & & \\
\hline \multirow[t]{2}{*}{ SCCmec type IVa } & $\mathrm{F}$ & GCC TTA TTC GAA GAA ACC G & 776 & \\
\hline & $\mathrm{R}$ & CTA CTC TTC TGA AAA GCG TCG & & \\
\hline \multirow[t]{2}{*}{ SCCmec type IVb } & $\mathrm{F}$ & TCT GGA ATT ACT TCA GCT GC & 493 & \\
\hline & $\mathrm{R}$ & AAA CAA TAT TGC TCT CCC TC & & \\
\hline \multirow[t]{2}{*}{ ScCmec type IVc } & $\mathrm{F}$ & ACA ATA TTT GTA TTA TCG GAG AGC & 200 & \\
\hline & $\mathrm{R}$ & TTG GTA TGA GGT ATT GCT GG & & \\
\hline \multirow[t]{2}{*}{ SCCmec type IVd } & $\mathrm{F}$ & CTC AAA ATA CGG ACC CCA ATA CA & 881 & \\
\hline & $R$ & TGC TCC AGT AAT TGC TAA AG & & \\
\hline \multirow[t]{2}{*}{ ScCmec type $\mathrm{V}$} & $\mathrm{F}$ & GAA CAT TGT TAC TTA AAT GAG CG & 325 & \\
\hline & $\mathrm{R}$ & TGA AAG TTG TAC CCT TGA CAC C & & \\
\hline \multirow[t]{2}{*}{ mecA } & $\mathrm{F}$ & GTG AAG ATA TAC CAA GTG ATT & 147 & \\
\hline & $\mathrm{R}$ & ATG CGC TAT AGA TTG AAA GGA T & & \\
\hline \multirow[t]{2}{*}{ mec complex group $A$} & $\mathrm{~F}$ & CCC TTT TTA TAC AAT CTC GTT & 146 & \\
\hline & $\mathrm{R}$ & ATA TCA TCT GCA GAA TGG G & & \\
\hline \multirow[t]{2}{*}{ mec complex group B } & $\mathrm{F}$ & TAT TTT TGG GTT TCA CTC GG & 1,305 & \\
\hline & $\mathrm{R}$ & CTC CAC GTT AAT TCC ATT AAT ACC & & \\
\hline
\end{tabular}


을 실시하였다. 본 연구에 사용한 primer의 염기서열은 기존 연 구자료를 바탕으로 시행하였다[17].

\section{DNA 전기영동을 통한 Multiplex PCR 증폭산물의 확인 및 분석}

$0.5 \% \mathrm{TBE}$ buffer $30 \mathrm{~mL}$ 에 agarose $0.45 \mathrm{~g}$ 혼합 후, $\mathrm{DNA}$ 염 색을 위해 SYBR $^{\circledR}$ (Invitrogen, Carlsbad, CA, USA) $3 \mu \mathrm{L}$ 을 첨 가 하여 agarose gel을 만들었다. 완료된 PCR 산물을 $1.5 \%$ agarose/TBE gel의 각 well에 분주하여 $100 \mathrm{~V}, 20 \mathrm{~min}$ 전기영 동 시행 후 $100 \mathrm{bp}$ DNA ladder marker (Thermo Scientific, Waltham, MA, USA)와 비교하여 결과를 확인하였다(Table 2). 각각의 개별적인 $\mathrm{PCR}$ 증폭 반응은 $\mathrm{SCCmec}$ 유형과 mec complex 유형의 특이적인 loci에 대해 각각의 증폭산물의 크 기에 상응하는 별개의 밴드를 생성하였다.

\section{1) 중환자실 환경에서 세균의 분리 빈도}

중환자실 환경의 의료 영역 중 출입문 번호 키, 세면대, 업무 용 키보드, 유선전화기 등 4 개 영역에서 33 주(47.8\%), 의료진의 손에서는 11주(16.0\%), 환자 영역인 수액 조절펌프에서는 15 주(21.7\%), 비 의료진 병원종사자의 손에서는 10 주(14.5\%)의
세균이 분리됨을 확인 하였다(Table 3).

2) 중환자실 환경에서 그람양성알균과 MRSA의 분리 빈도 의료 영역 중 출입문 번호 키, 유 선전화기, 수액조절펌프에 서 각각 MRSA가 1 주씩 분리 되었으며, 비 의료진 병원종사자의 손에서는 methicillin susceptible $S$. aureus (MSSA) 1 주가 분 리 되었다. 중환자실 환경에서 분리 배양된 세균 중 그람양성알 균은 총 34주가 분리되었으며, 이중 S. aureus는 4건(11.8\%)이 분리되었고, 출입문 번호 키와 유선전화기, 수액조절펌프에서 각각 MRSA가 1주씩 분리 되었다(Table 4).

3) mecA 유전자 검출률 및 $\mathrm{Sccmec}$, mec complex subtype의 분포율

세균배양을 기초로 중환자실 환경에서 분리된 S. aurels 4 주 와 환자로부터 분리된 MRSA 20주의 임상분리균주를 대상으로 $m e c A$ 유전자의 보유 여부를 확인하기 위해 $m e c \mathrm{ACR}$ 분석을 실시한 결과, 중환자실 환경에서 분리되었던 4건의 $S$. aureus 중 3 건(75.0\%)이 mecA 유전자를 보유하고 있는 것으로 확인되 어 MRSA임이 확인 되었고, 환자에서 분리된 MRSA 20주는 모 두 mecA 유전자를 보유하고 있음을 확인 하였다. Multiplex

Table 3. Bacterial isolates from environmental surfaces of intensive care unit in a general hospital

\begin{tabular}{|c|c|c|c|c|c|}
\hline Microorganisms & HC Zone* & HCW Hand ${ }^{\dagger}$ & Non HCW Hand ${ }^{\ddagger}$ & Patient zone & Total (\%) \\
\hline Staphylococcus spp. & $8(24.2)$ & $8(72.7)$ & $7(70.0)$ & $8(53.3)$ & $31(45.0)$ \\
\hline Enterococcus spp. & $0(0)$ & $0(0)$ & $0(0)$ & $3(20.0)$ & $3(4.3)$ \\
\hline Bacillus spp. & $5(15.2)$ & $0(0)$ & $0(0)$ & $0(0)$ & $5(7.2)$ \\
\hline Gram positive rod & $15(45.5)$ & $3(27.3)$ & $3(30.0)$ & $3(20.0)$ & $24(35.0)$ \\
\hline Pantoea spp. & $1(3.0)$ & $0(0)$ & $0(0)$ & $0(0)$ & $1(1.4)$ \\
\hline Acinetobacter baumannii & $0(0)$ & $0(0)$ & $0(0)$ & $1(6.7)$ & $1(1.4)$ \\
\hline Pseudomonas spp. & $3(9.1)$ & $0(0)$ & $0(0)$ & $0(0)$ & $3(4.3)$ \\
\hline Acinetobacter spp. & $1(3.0)$ & $0(0)$ & $0(0)$ & $0(0)$ & $1(1.4)$ \\
\hline Total & $33(47.8)$ & $11(16.0)$ & $10(14.5)$ & $15(21.7)$ & $69(100)$ \\
\hline
\end{tabular}

*Health-care zone, ${ }^{\dagger}$ Health-care worker, ${ }^{\dagger}$ Non Health-care worker.

Table 4. Gram positive cocci and MRSA from environmental surfaces of intensive care unit in a general hospital

\begin{tabular}{lccccc}
\hline Hospital environment (surfaces) & SAU & EFM & SPE & Other CNS & Total (\%) \\
\hline Door number keypad & $1(50 .)^{\dagger}$ & $0(0)$ & $1(50.0)$ & $0(0)$ & $2(5.9)$ \\
Hand washing sink & $0(0)$ & $0(0)$ & $0(0)$ & $0(0)$ & $0(0)$ \\
Keyboard & $0(0)$ & $0(0)$ & $0(0)$ & $2(100)$ & $2(5.9)$ \\
Telephone & $1(33.3)^{\dagger}$ & $0(0)$ & $0(0)$ & $2(66.7)$ & $3(8.8)$ \\
Hcws hand & $0(0)$ & $0(0)$ & $5(62.5)$ & $3(37.5)$ & $8(23.5)$ \\
Non-Hcws hand & $1(14.3)^{\dagger}$ & $0(0)$ & $5(71.4)$ & $1(14.3)$ & $7(20.6)$ \\
Infusion pump & $1(9.1)^{\dagger}$ & $3(18.2)$ & $1(9.1)$ & $7(63.6)$ & $12(35.3)$ \\
Total (\%) & $4(11.8)$ & $3(8.8)$ & $12(35.3)$ & $15(44.1)$ & $34(100)$ \\
\hline
\end{tabular}

Abbreviations: MRSA, Methicillin-resistant Staphylococcus aureus; SAU, Staphylococcus aureus; EFM, Enterococcus faecium; CNS, Coagulase negative Staphylococcus; SPE, Staphylococcus epidermidis. 
$\mathrm{PCR}$ 분석을 통해 SCCmec typing을 수행한 결과 환자로부터 분리된 MRSA 총 20주 중 8주(40.0\%)가 SCCmec type II, 1주 (5.0\%)가 SCCmectype II \& IVa, 나머지 11주(55.0\%)는 모두 Not typeable로 분석되었으며, 중환자실 환경에서 분리된 총 3 주의 MRSA 중 SCCmectype II가 1주(33.3\%), SCCmectype III가 1주(33.3\%), SCCmec type IVa가 1주(33.3\%)로 각각 확 인되었다(Table 5). 추가적으로 Multiplex PCR 분석을 통해 mec complex typing을 수행한 결과 환자로부터 분리된 MRSA 총 20주 중 8주(40.0\%)가 mec complex type A, 1주 (5.0\%)가 mec complex type B, 나머지 11주(55.0\%)는 모두 not typeable로 분석되었으며, 중환자실 환경에서 분리된 총 3 주의 MRSA 중 mec complex type A가 1주(33.3\%), mec complex type B 가 1주(33.3\%), not typeable이 1주(33.3\%) 로 각각 확인되었다(Figures 1-3).

\section{고 찰}

S. aureus는 피부감염, 균혈증, 식중독, 폐렴 등 여러 감염증 을 일으키는 주요 병원체이며, 병원내 감염의 주요 원인균으로 빈번하게 분리되고 있다[18]. 균혈증이 발생한 경우 치명율이
$50 \%$ 이상으로 높게 나타나는 것으로 알려져 있고, 전이성 감염 등 합병증을 동반하는 것으로 알려져 있다[18]. MRSA에 의한 병원감염의 주요 감염원으로는 의료종사자, 오염된 의료기구, 인공호흡기, 서킷, 침대 난간, 약물 자동 주입기 등이 있으며, MRSA 뿐만 아니라 다른 종류의 다제내성균에 의해서도 병원 감염이 발생하는 것으로 보고되었다[7, 8]. Rampling 등[8]의 연구에 따르면 사물함, 의자, TV, 전화기 등의 가구나 전자기기, 바닥, 의료장비, 침대, 문손잡이, 인공호흡기, 방열기, 간호사 호 출 버튼 등에서도 MRSA가 존재하는 것으로 나타났다. 특히 겨 울철 주로 사용하는 방열기에서 $36.4 \%$ 로 $\mathrm{MRSA}$ 의 존재가 가장 높게 나타났고, 의료 장비에서 $13.2 \%$, 사물함 등 가구에서 $11.3 \%$, 문손잡이에서 $10.7 \%$ 가 MRSA가 분리되는 것으로 보고 되었다. 하지만, 본 연구에서는 출입문 번호 키에서 $\mathrm{MRSA}$ 의 분 리율이 $50.0 \%$, 전화기 $33.3 \%$, 약물 자동 주입기에서 $9.1 \%$ 로 나 타나 선행 연구와는 차이가 있지만 의료진이 주로 사용하는 약 물 자동 주입기 등 의료 장비에서 MRSA 보고는 의미 있는 것으 로 볼 수 있다(Table 1). 중환자실의 경우 면역이 저하되어 있는 환자들이 많기 때문에 병원감염에 이환 될 가능성이 높으며, 국 내 3차 의료기관에 나타나는 HA-MRSA는 다양한 유전형이 혼 재되어 있고, SCCmectype II형이 45\%로 가장 흔하지만 다른

Table 5. Typing of Staphylococcal cassette chromosome mec ( $\mathrm{SCC}$ mec) and mec complex from patients and environmental surfaces of intensive care unit in a general hospital

\begin{tabular}{|c|c|c|c|c|c|c|c|c|c|c|c|c|}
\hline \multirow{2}{*}{ Strain } & \multirow{2}{*}{$\begin{array}{c}\text { MRSA } \\
\text { mecA(147bp) }\end{array}$} & \multicolumn{2}{|c|}{ mec Complex Types } & \multicolumn{8}{|c|}{ SCCmec types } & \multirow{2}{*}{ Genotypes } \\
\hline & & Group A & Group B & I & II & III & IVa & $\mathrm{IVb}$ & IVc & $\mathrm{IVd}$ & V & \\
\hline MRSA-1 & + & + & - & - & + & - & - & - & - & - & - & Group A, II \\
\hline MRSA-2 & + & - & - & - & - & - & - & - & - & - & - & Not typeable \\
\hline MRSA-3 & + & + & - & - & + & - & - & - & - & - & - & Group A, II \\
\hline MRSA-4 & + & - & - & - & - & - & - & - & - & - & - & Not typeable \\
\hline MRSA-5 & + & - & - & - & - & - & - & - & - & - & - & Not typeable \\
\hline MRSA-6 & + & + & - & - & + & - & - & - & - & - & - & Group A, II \\
\hline MRSA-7 & + & - & - & - & - & - & - & - & - & - & - & Not typeable \\
\hline MRSA-8 & + & - & + & - & + & - & + & - & - & - & - & Group B, II IVa \\
\hline MRSA-9 & + & + & - & - & + & - & - & - & - & - & - & Group A, II \\
\hline MRSA-10 & + & + & - & - & + & - & - & - & - & - & - & Group A, II \\
\hline MRSA-11 & + & + & - & - & + & - & - & - & - & - & - & Group A, II \\
\hline MRSA-12 & + & - & - & - & - & - & - & - & - & - & - & Not typeable \\
\hline MRSA-13 & + & + & - & - & + & - & - & - & - & - & - & Group A, II \\
\hline MRSA-14 & + & - & - & - & - & - & - & - & - & - & - & Not typeable \\
\hline MRSA-15 & + & - & - & - & - & - & - & - & - & - & - & Not typeable \\
\hline MRSA-16 & + & - & - & - & - & - & - & - & - & - & - & Not typeable \\
\hline MRSA-17 & + & - & - & - & - & - & - & - & - & - & - & Not typeable \\
\hline MRSA-18 & + & + & - & - & + & - & - & - & - & - & - & Group A, II \\
\hline MRSA-19 & + & - & - & - & - & - & - & - & - & - & - & Not typeable \\
\hline MRSA-20 & + & - & - & - & - & - & - & - & - & - & - & Not typeable \\
\hline MRSA-E 1 & + & - & - & - & - & + & - & - & - & - & - & III \\
\hline MRSA-E 9 & + & - & + & - & - & - & + & - & - & - & - & Group B, IVa \\
\hline MRSA-E16 & - & - & - & - & - & - & - & - & + & - & - & IVC \\
\hline MRSA-E21 & + & + & - & - & + & - & - & - & - & - & - & Group A, IVc \\
\hline
\end{tabular}


아형이 혼재되어 존재하는 것으로 보고된 바 있다[19]. 대부분 의 HA- MRSA는 SCCmectyping 분석 결과 SCCmectype II형 또는 III형이 우세하고, CA-MRSA 감염의 경우 SCCmec type $\mathrm{IV}$ 형 또는 V형의 균주가 우세한 것으로 알려져 있다[20]. $S$. aureus 감염이 의심되는 임상에서는 CA-MRSA 뿐만 아니라 $\mathrm{CA}-\mathrm{MSSA}$ 감염증을 구별하고 중증으로 이환되기 이전에 적절 한 항균제를 선택하여 적용하는 것이 환자에게 매우 중요하다 [20]. 일반적으로 $\mathrm{CA}-\mathrm{MRSA}$ 의 경우 어린이, 군인, 재소자, 혈관 내 약물 남용(Intravenous drug abuse, IVDA) 등에서 빈번히 발생하며 SCCmectype IV형이 주로 나타나며, $\beta$-lactam 계열 의 항균제에 내성을 가지고 있는 것으로 알려져 있다. 반면, $\mathrm{HA}-\mathrm{MRSA}$ 는 장기 요양시설이나, 당뇨 또는 투석환자 등에서 발생할 수 있으며 SCCmectype I, II, III형이 주로 나타나며, 다 제내성(Multidrug resistance, MDR)을 가지고 있는 것으로 알 려져 있다[20]. Ameer 등[21]의 해외 연구에서는 CA-MRSA와 $\mathrm{HA}-\mathrm{MRSA}$ 의 유병률 조사 결과 $\mathrm{CA}-\mathrm{MRSA}$ 는 $28.9 \%$, HA$\mathrm{MRSA}$ 는 $71.1 \%$ 로 나타났고 항균제 내성률 조사 결과 $\mathrm{HA}^{-}$ $\mathrm{MRSA}$ 의 경우 erythromycin에 대한 내성률이 $62.9 \%$, ciprofloxacin에 대한 내성률이 $54.5 \%$, tetracycline에 대한 내성률 이 $21.7 \%$, teicoplanin에 대한 내성률이 $16.1 \%, \mathrm{CA}-\mathrm{MRSA}$ 의 경우 erythromycin에 대한 내성률이 $56.9 \%$, ciprofloxacin에 대한 내성률이 $48.3 \%$, tetracycline에 대한 내성률이 $15.5 \%$,

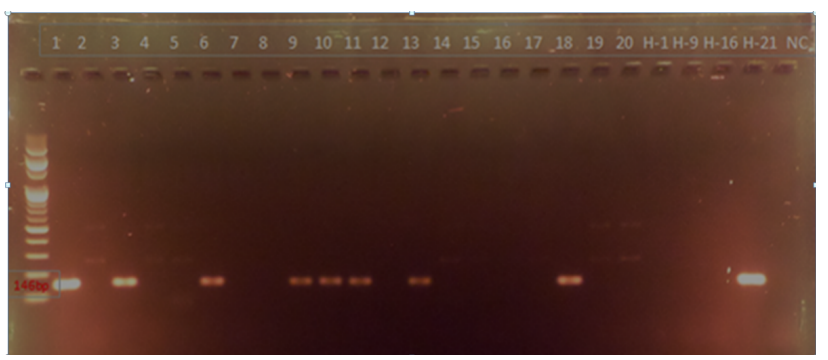

Figure 1. Multiplex PCR assay identifies mec complex and subtypes simultaneously detects the methicillin resistance (mec complex group A).

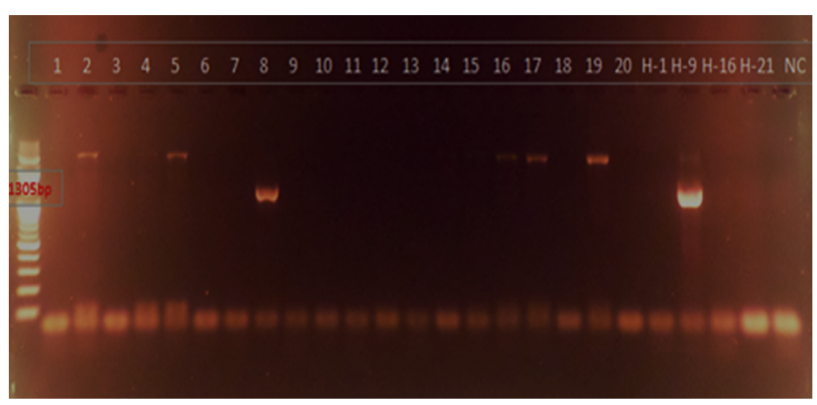

Figure 2. Multiplex PCR assay identifies mec complex and subtypes simultaneously detects the methicillin resistance (mec complex group B). teicoplanin에 대한 내성률이 13.8\%로 CA-MRSA와HA-MRSA 의 내성률이 $6 \%$ 내외로 비슷하게 나타났으나 clindamycin에 대한 HA-MRSA의 내성률은 $46.2 \% \mathrm{CA}-\mathrm{MRSA}$ 의 내성률은 $22.4 \%$ 였으며, gentamicin에 대한 HA-MRSA의 내성률은 $46.2 \% \mathrm{CA}-\mathrm{MRSA}$ 의 내성률은 $20.7 \%$ 로 $\mathrm{HA}-\mathrm{MRSA}$ 에서의 내성 률이 2 배 이상의 내성으로 보고되었다[22]. 또한 국내의 선행연 구 결과에 따르면 CA-MRSA가 병실이나 중환자실에서 약 $25 \%$ 정도 분리되는 것으로 보고되고 있으며, 항균제 감수성 시험 결 과 oxacillin 이외 erythromycin에 대한 내성률은 83.6\%, ciprofloxacin에 대한 내성률은 $53.4 \%$, trimethoprim/ sulfamethoxazole에 대한 내성률은 4.1\%, rifampin에 대한 내 성률은 $10.9 \%$ 인 것으로 보고되었다[21]. 임상검체에서 분리된 MRSA 균주의 mec complex typing 결과 mec complex group A는 8건(40\%), mec complex group B는 1건(5\%), not typeable은 11건(55\%)으로 나타났다(Figures 1-3). mec complex group A형 8건(40\%)은 모두 SCCmec type II형, mec complex group B형 1(5\%)건은 SCCmec type II \& IVa 형, mec complex typing에서 not typeable로 나온 11건 (55\%)은 모두 SCCmec typing에서도 not typeable의 결과를 나타냈다. 중환자실의 환경에서 분리된 $\mathrm{MRSA}$ 를 $\mathrm{mec}$ complex typing한 결과 mec complex group A, group B, not typeable이 각각 1건(33.3\%)으로 나타났다(Table 5). 임상검 체에서는 주로 SCCmec type II형과 II형 \& IVa형, not typeable로 분석되었으며, 중환자실 환경검체에서는 SCCmec Type II형, III, IVa형을 확인할 수 있었고, 나머지 1주는 Methicillin에 감수성을 보이는 MSSA로 분석되었다. 임상검체 와 중환자실 환경검체에서 분리된 MRSA의 SCCmectyping 분 석 결과 임상검체 대부분이 not typeable로 가장 우세하게 나타 났고, 다음으로 SCCmec type II형이 우세한 것으로 확인 되었 으며, 이는 HA-MRSA에서 SCCmectype II형이 가장 우세하다 는 기존의 연구결과와 유사한 결과를 보였으며, 중환자실 환경

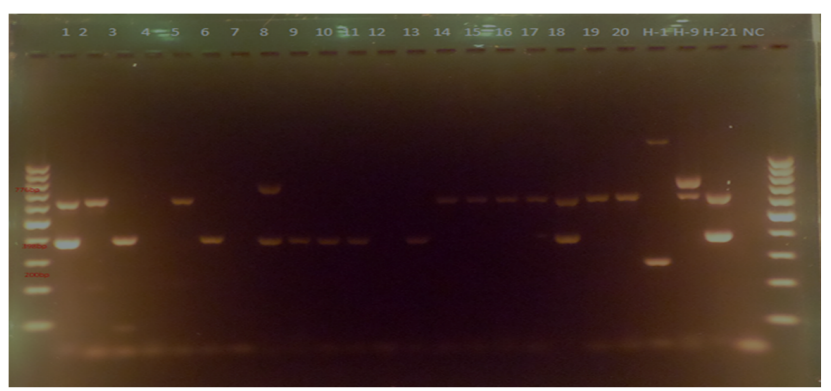

Figure 3. Multiplex PCR assay identifies SCCmec types and subtypes simultaneously detects the methicillin resistance (SCC mec subtypes). 
검체는 대부분이 SCCmec type II형, III형, IVa형으로 나타나 기존의 연구결과와는 약간 상이한 결과를 나타냈다[20]. 임상 분리 MRSA 중 1 개 균주와 중환자실 환경분리 MRSA 중 2균주 가 $\mathrm{CA}-\mathrm{MRSA}$ 로 확인 되었으며, 나머지 $\mathrm{MRSA}$ 균주들은 HA-MRSA로 확인되었다 (Table 4). 임상검체와 중환자실 환경 검체에서 분리된 MRSA는 SCCmec typing 결과 origin이 서로 다른 것으로 나타나 임상에서 분리된 MRSA가 환경으로부터 이 환되지 않았다는 것을 알 수 있었으나 의료기관 환경에서의 SCCmec type II형이 1건(33.3\%) 나타난 것은 의료종사자의 손, 가운 등을 매개체로 하여 환경내의 MRSA가 환자에게 전파 되었을 가능성이 있는 것으로 사료된다 (Table 5). Du XF 등 [23]은 Multiple-locus variable number of tandem repeat fingerprinting(MLVF), spa typing, multilocus sequence typing (MLST)/SCCmec and pulse field gel electrophoresis (PFGE)를 이용한 SCCmectyping을 추적 조사하여 상세한 결 과를 조사하여 발표한 바 있으나, 이런 연구는 고가의 장비가 필 요하고 분석시간이 오래 소요되고, 분석 과정이 복잡하기 때문 에 분리균주 수가 적은 중 - 소규모의 병원에서는 실험이 불가 능한 상황이다.

본 연구에서는 국내의 지방 의료기관에서의 중환자실 감염 관리 수준을 $\mathrm{MRSA}$ 의 mec유전자의 타입을 분석하는 정도로 보 고하고 있지만, 이러한 점 만으로도 병원감염과 관련된 감염원 을 추적하는데 도움이 될 것으로 생각되며, 이후 추가적인 연구 를 통해 좀 더 많은 수의 병원감염 관련 균주를 대상으로 추적조 사를 한다면 임상 현장에 더욱 유용한 정보를 제공할 수 있을 것 으로 사료된다. 중환자실의 특성상 일반 병실보다 중증 환자가 집중되어 있어 감염관리의 중요성이 증가하고 있고, 병원 감염 및 다제 내성 세균을 포함한 감염성 질환자에 대한 적절한 격리 및 방문객 제한, 주변 환경에 대한 철저한 소독 등 병원 내 환경 관리의 요구도가 높아지고 있으나 이와 관련된 국내에서의 연 구는 미흡한 실정이다. Lin 등[24]은 meta-analysis을 통해 non-hospital 환경오염 시료에서 SCCmec typing을 추적 조 사해 보고한 바 있다. 본 연구에서 임상검체로부터 분리된 MRSA 중 SCCmec과 mec complex typing에서 not-typeable 의 결과를 나타낸 균주들의 경우 추가적인 분석을 통해 국내에 특이적으로 존재하는 다른 아형의 균주인지에 대한 후속 연구 가 필요할 것으로 사료된다. 중환자실로 국한된 환경검체의 경 우 의료기관 내 감염관리가 중요한 부서를 확대하여 관리함으 로써 MRSA에 의한 병원감염을 예방하고 의료종사자에게 이와 관련된 정보를 제공함으로써 의료기관 내 감염관리에 있어서 중요한 역할을 할 것으로 기대된다.

\section{요 약}

본 연구에서는 2017년 6월부터 7월까지 국내 충남 소재 2차 의료기관의 임상검체에서 분리 된 20개 균주와 ICU환경으로부 터 분리 한 4 개를 포함해 총 24 개의 MRSA 균주에 대한 분자유 전학적 특성을 분석하기 위해 SCCmectyping과 mec complex typing을 수행하였다. 임상검체에서 분리된 MRSA 20균주의 SCCmectyping 분석 결과 SCCmectype II가 8건, type IVa 가 1 건, Not-typeable이 11건으로 나타났다. 의료기관 중환자실 환경에서 분리 된 MRSA 중 한 균주는 mecA 유전자를 가지고 있지 않은 것으로 확인되었으며, 나머지 세 균주는 SCCmec type II, III, IVa가 각각 한 건으로 나타났다. 임상검체와 중환자 실 환경검체에서 분리된 MRSA는 SCCmec typing 결과 그 기 원이 서로 다른 것으로 나타났으나, 의료기관 환경에서 분리된 1 건의 경우 그 기원이 서로 일치하여 의료종사자의 손, 가운 등 을 매개체로 하여 환경내의 MRSA가 환자에게 전파되었을 가능 성이 있는 것으로 사료된다. 이후 추가적인 연구를 통해 좀 더 많 은 수의 병원감염 관련 균주를 대상으로 추적조사를 실시 한다 면 임상 현장에 감염관리와 관련한 더욱 유용한 정보를 제공할 수 있을 것으로 사료된다.

\section{Acknowledgements: None \\ Conflict of interest: None}

\section{REFERENCES}

1. Kwak YG, Cho YK, Kim JY, Lee MS, Kim HY, Kim YK, et al. Korean Nosocomial Infections Surveillance System, intensive care unit module report: data summary from July 2009 through June 2010. Korean J Nosocomial Infect Control. 2011;16:1-12.

2. CDC. CDC web sites on CDC/NHSN surveillance definitions for specific types of infections. [Internet]. Atlanta; CDC; 2014 [cited 2018 May 19]. Available from: http://www.cdc.gov/ nhsn/pdfs/pscmanual/17pscnosinfdef_current.pdf.

3. Diaz Granados CA, Zimmer SM, Mitchel K, Jernigan JA. Comparison of mortality associated with vancomycin-resistant and vancomycin-susceptible enterococcal bloodstream Infections: a Meta-analysis. Clinical Infect Dis. 2005;41:327-333.

4. Kim YA, Lee HM, Lee KW. Contamination of the hospital environmental by pathogenic bacteria and infection control. Korean J Nosocomial Infect Control. 2015;20:1-6.

5. CDC. CDC web sites on guidelines for environmental infection control in health-care facilities [Internet]. Atlanta; CDC; 2003 [cited 2018 May 19]. Available from: http://www.cdc.gov/hicpac/pdf/guidelines/eic_in_hcf_03.pdf.

6. Kim HJ, Lee JC, et al. The Korean society for microbiology textbook of medical microbiology. 4th ed. Killiney: Elsevier; 2005. 
p343-347.

7. Muscarella LF. Contribution of tap water and environmental surfaces to nosocomial transmission of antibiotic-resistant Pseudomonas aeruginosa. Infect Control Hosp Epidemiol. 2004;25:342-345.

8. Rampling A, Wiseman S, Davis L, Hyett AP, Walbridge AN, Payne GC, et al. Evidence that hospital hygiene is important in the control of methicillin-resistant Staphylococcus aureus. J Hosp Infect. 2001;49:109-116.

9. van Duijn PJ, Dautzenberg MJ, Oostdijk EA. Recent trends in antibiotic resistance in European ICUs. Curr Opin Crit Care. 2011;17:658-665.

10. Kim US, Bang JH, Kim HB, Park SW, Oh MD, Song YW, et al. Epidemiology of and risk factors for methicillin resistance in community-acquired and nosocomial Staphylococcus aureus bacteremia. Korean J Infect Dis. 1999;31:325-331.

11. Jung HJ, Jung MG, Kim WJ, Park SC. Clinical significance of staphylococcus aureus bacteremia. Korean J Inf. 1994;26: 255-62.

12. Berglund C, Mölling P, Sjöberg L, Söderquist B. Predominance of staphylococcal cassette chromosome mec (SCCmec) type IV among methicillin-resistant Staphylococcus aureus (MRSA) in a Swedish county and presence of unknown SCCmec types with Panton-Valentine leukocidin genes. Clin Microbiol Infect. 2005;11:447-456.

13. Fey PD, Said-Salim B, Rupp ME, Hinrichs SH, Boxrud DJ, Davis $\mathrm{CC}$, et al. Comparative molecular analysis of community- or hospital-acquired methicillin -resistant Staphylococcus aureus. Antimicrob Agents Chemohter. 2003;47:196-203.

14. Patrozou E, Reid K, Jefferson J, Mermel LA. A cluster of community-acquired methicillin-resistant staphylococcus aureus infections in hospital security guards. Infect Control Hosp Epidemiol. 2009;30:386-388.

15. Lowy FD. Staphylococcus aureus infections. N Engl J Med. 1998;339:520-532.

16. Chong Y, Lee K. Present situation of antimicrobial resistance in
Korea. J Infect Chemother. 2000;6:189-195.

17. Zhang K, McClure JA, Elsayed S, Louie T, Conly JM. Novel multiplex PCR assay for characterization and concomitant subtyping of staphylococcal cassette chromosome mectypes I to V in methicillin-resistant Staphylococcus aureus. J Clin Microbiol. 2005;43:5026-5033.

18. Lee SO, Kim S, Lee J, Kim KM, Kim BH, Kim ES, et al. Korean nosocomial infections surveillance system report: data summary from July 2015 through June 2016. Korean Journal of Nosocomial Infection Control. 2006;11:113-128.

19. Ko KS, Lee JY, Suh JY, Oh WS, Peck KR, Lee NY, et al. Distribution of major genotypes among methicillin-resistant Staphylococcus aureus clones in Asian countries. J Clin Microbiol. 2005;43:421-426.

20. Okuma KK, Iwakawa JD, Turnidge WB, Grubb JM, Bell FG, O'Brien FG, et al. Dissemination of new methicillin-resistant Staphylococcus aureus clones in the community. J Clin Microbiol. 2002;40:4289-4294.

21. Ameer Abbas, Nirwan PS, Srivastava P. Prevalence and antibiogram of HA-MRSA and CA-MRSA at a tertiary care hospital NIMS. Community Acquired Infection. 2015;2:13-15.

22. Song JS, Choe PG, Song KH, Cho JH, Kim SH, Bang JH, et al. Multicenter study for frequency and clinical features of community-associated methicillin-resistant Staphylococcus aureus in Korea. Infect Chemother. 2006;38:325-333.

23. Du XF, Xiao M, Liang HY, Sun Z, Jiang YH, Chen GY, et al. An improved MLVF method and its comparison with traditional MLVF, spa typing, MLST/SCCmec and PFGE for the typing of methicillin-resistant Staphylococcus aureus. Int J Mol Sci. 2014;15:725-742.

24. Lin J, Lin D, Xu P, Zhang T, Ou Q, Bai C, et al. Non-hospital environment contamination with Staphylococcus aureus and methicillin-resistant Staphylococcus aureus: proportion meta-analysis and features of antibiotic resistance and molecular genetics. Environ Res. 2016;150:528-540. 